Pteridines

Vol. 17, 2006, pp. $69-73$

\title{
Tetrahydrobiopterin Regulates L-tyrosine-induced Elevation of Cytosolic Calcium Concentration in Insulin-secreting Cells
}

\author{
Masakazu Ishii, Shunichi Shimizu, Tatsuya Watabe, Yuji Kiuchi \\ Department of Pathophysiology, School of Pharmaceutical Sciences, Showa University, Tokyo 142-8555, Japan
}

\begin{abstract}
We examined the role of endogenous tetrahydrobiopterin $\left(\mathrm{BH}_{4}\right)$ on $\mathrm{L}$-tyrosine-induccd increase in cytosolic $\mathrm{Ca}^{2}$ concentration $\left(\left[\mathrm{Ca}^{2}\right]_{i}\right)$ in the $\beta$-cell line, HIT-T 15. Addition of L-tyrosine to the cells increased $\left[\mathrm{Ca}^{2}\right]_{i}$ in a concentration-dependent manner. Morcover, the L-tyrosine-induced [ $\left.\mathrm{Ca}^{-}\right]_{\mathrm{i}}$ elevation was blocked by L-3,4-dihydroxyphenylalanine ( $\mathrm{L}$-DOPA). Under low levels of $\mathrm{BH}_{4}$ by treatment with 2,4-diamino-6-hydroxypyrimidine (DAHP), an inhibitor of $\mathrm{BH}_{4}$ biosynthesis, elevation of $\left[\mathrm{Ca}^{-}\right]_{i}$ by L-tyrosine was stimulated. Moreover, co-pretreatment with sepiapterin, a precursor of $\mathrm{BH}_{4}$ biosynthesis, reduced the decrease of $\mathrm{BH}_{4}$ content by $\mathrm{DAHP}$, and suppressed L-tyrosine-induced $\left[\mathrm{Ca}^{2}\right]_{i}$ elevation in DAHP-pretreated cells. These findings suggest that $\mathrm{BH}_{4}$ negatively regulates $\mathrm{L}$-tyrosine-induced $\left[\mathrm{Ca}^{2}\right]_{i}$ elevation via the production of L-DOPA in $\beta$-cells.
\end{abstract}

Key words: $\quad$ tetrahydrobiopterin, calcium, L-tyrosinc, $\beta$-cell

\section{Introduction}

Numerous insulinotropic substances including glucose, fatty acid and amino acid have been shown to increase insulin secretion with elevation of $[\mathrm{Ca}]_{\mathrm{i}}$ through the plasma membrane $\mathrm{Ca}^{2}$ channels including L-type voltage-operated $\mathrm{Ca}^{2}$ channel and transient receptor potential TRPM 2 channel (1-5). Recent studies showed that insulin secretion is controlled by $\mathrm{Ca}^{2}$ release from intracellular stores in the endoplasmic reticulum as well as $\mathrm{Ca}^{2}$ influx from extracellular spaces $(6,7)$. Thus, it is widely accepted that the increase in $\left[\mathrm{Ca}^{2}\right]_{i}$ is essential for the beginning of insulin secretion in pancreatic $\beta$-cells.

Tetrahydrobiopterin $\left(\mathrm{BH}_{4}\right)$ is an essential cofactor not only for nitric oxide (NO) synthases but also for aromatic L-amino acid hydroxylases including tyrosine hydroxylase $(8,9)$. In diabetic conditions, the content of $\mathrm{BH}_{4}$ is decreased in vessels (10) and brain (11). It is possible that $\mathrm{BH}_{4}$ content may be decreased in diabetic $\beta$-cells. In our previous study, the decrease in $\mathrm{BH}_{4}$ content may have promoted the L-arginineinduced $\left[\mathrm{Ca}^{2}\right]_{i}$ elevation through the reduction of NO production (12). L-Tyrosine, a substrate of tyrosine hydroxylase, is known to stimulate insulin secretion in the presence of glucose (13). Moreover, it is known that L-DOPA, a product of tyrosine hydroxylase, reduces glucose-induced insulin secretion (13). Therefore, it is possible that L-DOPA may also reduce $\mathrm{L}$-tyrosine-induced insulin secretion. We hypothesize that the decrease in $\mathrm{BH}_{4}$ content also stimulates $\mathrm{L}$ tyrosine-induced insulin secretion through the reduction of tyrosine hydroxylase activities. In the present study, we examined the role of $\mathrm{BH}_{4}$ on L-tyrosineinduced $\left[\mathrm{Ca}^{2}\right]$, elevation using HIT-T 15 cells, from a hamster pancreatic $\beta$-cell line.

\section{Materials and Methods}

Cell culure

Hamster pancreatic $\beta$-cell line, HIT-T15 cells (Dainippon Pharmaceutical Co., Osaka, Japan; passages 70-85) were cultured in Ham'F 12 medium containing $10 \%$ fetal bovine serum (FBS), $100 \mathrm{U} / \mathrm{ml}$ penicillin and $100 \mu \mathrm{g} / \mathrm{mL}$ streptomycin.

Measurement of changes in / $\mathrm{Ca} /$,

Cells on coverslips were loaded with fura-2 in HEPES-buffered saline (HBS) containing (in mM) 107

Correspondence to: Masakazu Ishii, Ph.D., Department of Pathophysiology, School of Pharmaceutical Sciences, Showa University, 1-5-8 Hatanodai. Shinagawa-ku, Tokyo 142-8555, Japan. Tel: ++81-3-3784-8041, Fax: ++8I-3-3786-(048I, E-mail: masakazu(apharm.showa-u.ac.jp 
$\mathrm{NaCl}, 6 \mathrm{KCl}, 1.2 \mathrm{MgSO}_{4}, 2 \mathrm{CaCl}_{2}, 11.5$ glucose, 20 HEPES, adjusted to $\mathrm{pH} 7.4$ with $\mathrm{NaOH}$. Cells were incubated with HBS containing $5 \mu \mathrm{M}$ fura-2/AM (Dojindo Laboratories, Kumamoto, Japan) and $0.1 \%$ bovine serum albumin at $37^{\circ} \mathrm{C}$ for $40 \mathrm{~min}$. The fura-2loaded cells were then incubated with HBS for $20 \mathrm{~min}$. The coverslips were then placed in a perfusion chamber mounted on the stage of the microscope. Fluorescence images of the cells were recorded and analyzed with a video images analysis system (MetaFluor, Nippon Roper, Osaka, Japan). Fluorescence emission at $510 \mathrm{~nm}$ was monitored with excitation at $340 \mathrm{~nm}$ and $380 \mathrm{~nm}$. The pairs of $340 \mathrm{~nm}$ and $380 \mathrm{~nm}$ fluorescence images were captured every $5 \mathrm{sec}$ and the $340 / 380 \mathrm{~nm}$ ratio was calculated after subtraction of background fluorescence. Data from all measurements are expressed as the fluorescence ratio of $340 / 380 \mathrm{~nm}$.

\section{Measurement of total biopterin content}

HIT-T 15 cells in 6 -well plates $(3.5 \times 10$ cells/well $)$ were directly treated with $0.02 \mathrm{M} \mathrm{KI} / \mathrm{I}_{2}$ in $0.1 \mathrm{M} \mathrm{HCl}$. and total bioptcrin $\left(\mathrm{BH}_{4}\right.$ plus 7,8-dihydrobiopterin $\left(\mathrm{BH}_{2}\right)$ plus biopterin) was measured, as previously described (14).

\section{Materials}

L-Tyrosine and L-DOPA were from Wako Pure Chemicals (Osaka, Japan). 2.4-Diamino-6-hydroxypyrimidine (DAHP) was from Aldrich Chemical Co. (Tokyo, Japan). Sepiapterin was from Funakoshi (Tokyo, Japan). All other reagents were of the highest grade commercially available.

\section{Statistical analys is}

Data are presented as means \pm S.E.M. of $n$ observations. The statistical significance of obscrved differences was determined by analysis of variance followed by Bonferroni's method. Differences between means were considered significant when $P$ was less than 0.05 .

\section{Results}

\section{Changes in $\left[\mathrm{Ca}^{\circ}\right]$, by L-tyrosine}

We examined whether L-tyrosine ( $5 \mathrm{mM}$ ), the substrate of tyrosine hydroxylase, induces $\mathrm{Ca}^{2}$ response in HIT-T 15 cells. Addition of L-tyrosine $(0.1-10 \mathrm{mM})$ to HIT-T 15 cells increased $\left[\mathrm{Ca}^{2}\right]_{i}$ in a concentrationdependent manner (Figure 1). Moreover, the L-tyrosine-induced $\left[\mathrm{Ca}^{2}\right]_{i}$ clevation was inhibited by $\mathrm{L}$ DOPA, the product of tyrosine hydroxylase (Figure 2).

Effect of $\mathrm{BH}_{4}$ on l-tyrosine-induced $\mathrm{Ca}$ response To determine whether L-tyrosine-induced $\mathrm{Ca}^{2}$
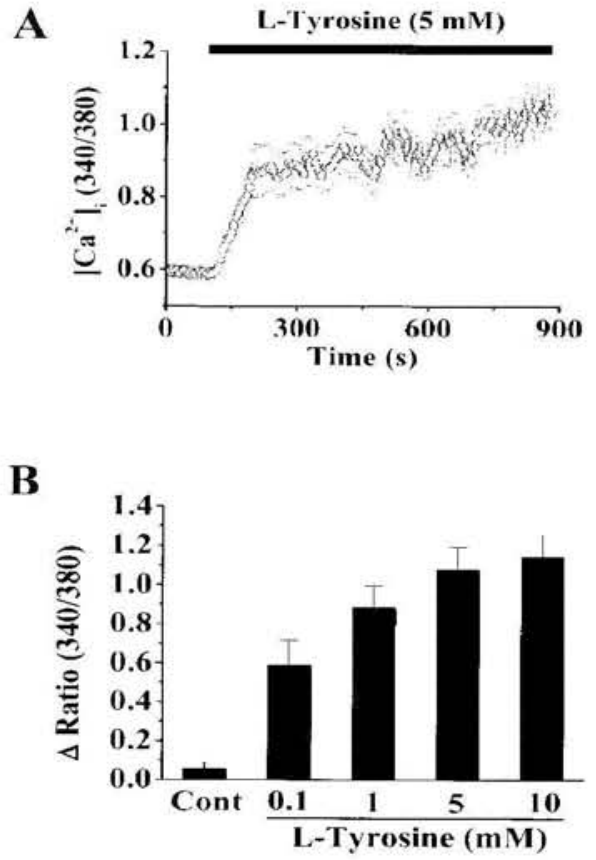

Figure 1 L-Tyrosine-induced $\left[\mathrm{Ca}^{2}\right]_{\mathrm{i}}$ clevation in HITT15 cells. Cytosolic $\mathrm{Ca}^{2 \cdot}$ was measured using fura-2 as a $\mathrm{Ca}^{2}$ indicator. In $\mathrm{A}$, cells were treated with $\mathrm{L}$ tyrosine $(5 \mathrm{mM})$. [ $\left[\mathrm{Ca}^{2}\right]_{i}$ is expressed as a fura-2 fluorescence ratio $(340 / 380 \mathrm{~nm})$. In $\mathrm{B}$, the effect of $\mathrm{L}$ tyrosine $(0.1-10 \mathrm{mM})$ in $\left[\mathrm{Ca}^{2}\right]_{\mathrm{i}}$ was measured in individual cells. The ratio in panel $B$ indicates the absolute changes of ratio intensity ( $\Delta$ ratio $(340 / 380$ $\mathrm{nm})=$ peak ratio - resting ratio). Results are the means \pm SEM of $15-43$ cells.

response is regulated by intracellular $\mathrm{BH}_{4}$ content, the effects of DAHP, the inhibitor of $\mathrm{BH}_{4}$ synthesis, and sepiapterin, the precursor of $\mathrm{BI}_{4}$ biosynthesis, were examined. As shown in Figure $3 \mathrm{~A}$, we measured the total biopterin content $\left(\mathrm{BH}_{4}\right.$ plus more oxidized forms) in HIT-TI 5 cells, which were treated with DAHP (I $\mathrm{mM})$ and or sepiapterin $(1-100 \mu \mathrm{M})$ for $6 \mathrm{~h}$. Treatment with DAHP reduced intracellular biopterin content (Figure $3 \mathrm{~A}$ ), and its decrease of intracellular biopterin content was recovered to control levels with co-treatment with sepiapterin $(10 \mu \mathrm{M})$. L-lyrosine-induced $\left[\mathrm{Ca}^{-}\right]_{\text {i }}$ elevation was stimulated in DAHP-treated cells, and its stimulation response was reduced by co-treatment with sepiapterin (10 $\mu \mathrm{M})$ (Figure 3B).

\section{Discussion}

It is well known that $\left[\mathrm{Ca}^{2-}\right]_{i}$ elevation stimulates insulin secretion in pancreatic $\beta$-cells $(1-7)$. In the present study, we measured real-time changes in $\left[\mathrm{Ca}^{-\cdot}\right]_{i}$ in a hamster pancreatic b-cell linc, HIT-T 15 cclls, in 
A

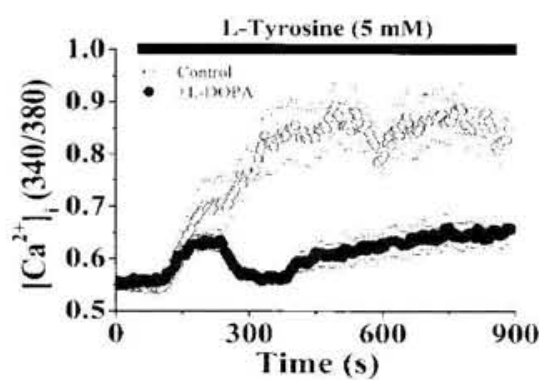

B

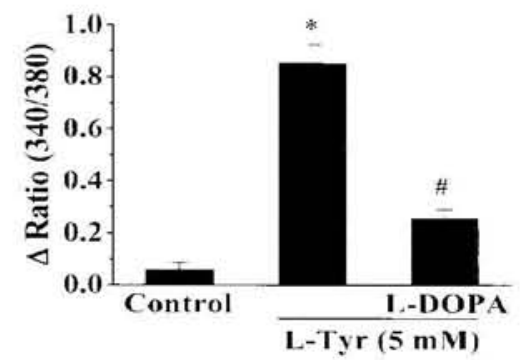

Figure 2 Effect of L-DOPA on L-tyrosine-induced $\left[\mathrm{Ca}^{2}\right]_{i}$ elevation in HIT-T15 cells. In A, cells were treated with L-tyrosine $(5 \mathrm{mM})$ in the presence of $\mathrm{L}$ DOPA $(5 \mathrm{mM})$. $\left[\mathrm{Ca}^{2}\right]_{\mathrm{i}}$ is expressed as a fura- 2 fluorescence ratio $(340 / 380 \mathrm{~nm})$. In $\mathrm{B}$. the effect of $\mathrm{L}$ DOPA on the peak levels of L-tyrosine $(5 \mathrm{mM})$ induced $\left[\mathrm{Ca}^{2}\right]_{i}$ elevation was measured. Cells were pretreated with L-DOPA $(5 \mathrm{mM})$ for $5 \mathrm{~min}$. The ratio in panel $\mathrm{B}$ indicates the absolute changes of ratio intensity $(\Delta$ ratio $(340 / 380 \mathrm{~nm})=$ peak ratio - resting ratio). Results are the means \pm SEM of 30-55 cells. *Significant changes in comparison to control group $(\mathrm{p}<0.05)$. \#Significant changes in comparison to Ltyrosine $(5 \mathrm{mM})$-treated group $(\mathrm{p}<0.05)$.

order to estimate the role of $\mathrm{BH}_{4}$, which is the cofactor of tyrosine hydroxylase, on insulin secretion by Ltyrosine. The decrease in $\mathrm{BH}_{4}$ content promoted $\mathrm{L}$ tyrosine-induced $\left[\mathrm{Ca}^{2}\right]_{i}$ elevation. Its response was significantly reduced to control levels by co-treatment with sepiapterin. These findings suggest that endogenous $\mathrm{BH}_{4}$ may negatively regulate L-tyrosine-induced $\left[\mathrm{Ca}^{\prime}\right]_{\mathrm{i}}$ elevation.

Tyrosine hydroxylase is present in many kinds of animal tissues (9). Lindstrom and Sehlin (13) reported that L-DOPA decreases glucose-induced insulin secretion from the pancreatic islet. L-Tyrosine is known to stimulate glucose-induced insulin secretion (13). In this study, we observed that treatment with L-DOPA reduces the L-tyrosine-induced $\left[\mathrm{Ca}^{2}\right]_{i}$ elevation in the presence of glucose. It is known that L-DOPA is rapidly converted to dopamine by aromatic L-amino acid
A

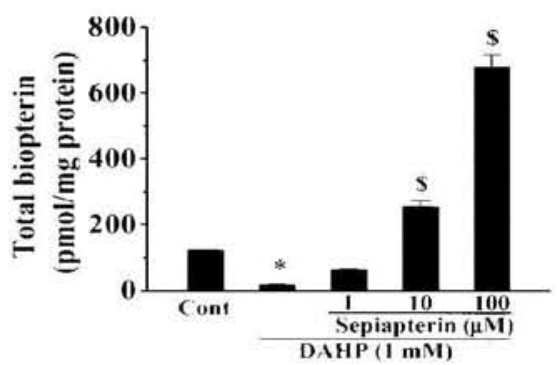

B

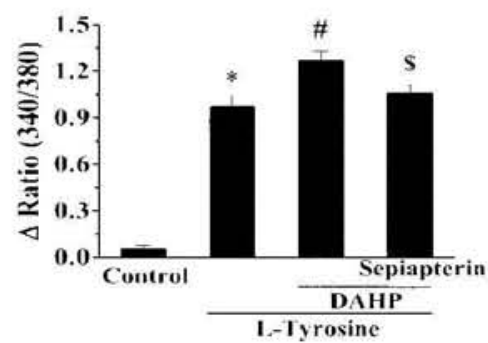

Figure 3 Effects of intracellular biopterin on L-tyrosine-induced $\left[\mathrm{Ca}^{2}\right]_{\mathrm{i}}$ elevation in HIT-T15 cells. In A, cells were incubated with DAHP $(1 \mathrm{mM})$ and sepiapterin $(1-100 \mu \mathrm{M})$ for $6 \mathrm{~h}$. Total biopterin levels were determined. In $\mathrm{B}$, the effects of pretreatment with DAHP $(1 \mathrm{mM})$ and/or DAHP $(1 \mathrm{mM})$ and sepiapterin $(10 \mu \mathrm{M})$ on the peak levels of L-tyrosine $(5 \mathrm{mM})$ induced $\left[\mathrm{Ca}^{2}\right]$ elevation was measured. Cells were pretreated with DAHP $(1 \mathrm{mM})$ and/or sepiapterin $(10$ $\mu \mathrm{M})$ for $6 \mathrm{~h}$. The ratio in panel $\mathrm{B}$ indicates the absolute changes of ratio intensity $(\Delta$ ratio $(340 / 380 \mathrm{~nm})$ - peak ratio - resting ratio). Results are the average of 53-74 cells. Results are the means \pm SEM of $30-55$ cells. *Significant changes in comparison to control group $(\mathrm{p}<0.05)$. \#Significant changes in comparison to Ltyrosine ( $5 \mathrm{mM})$-treated group $(\mathrm{p}<0.05)$. \$Significant changes in comparison to DAHP (1 $\mathrm{mM})$-treated group $(\mathrm{p}<0.05)$.

decarboxylase (14.15). L-Tyrosine hydroxylase activity is regulated by the feedback inhibition of dopamine (9). Lnder the decrease in $\mathrm{BH}_{4}$ content, the conversion of L-tyrosine to L-DOPA may be reduced. Thus, the production of dopamine from L-DOPA is also likely to be decreased. Therefore. $\mathrm{BH}_{4}$ may negatively control L-tyrosine-induced $\left[\mathrm{Ca}^{2}\right]_{i}$ elevation through production of dopamine in the presenee of glucose. The inhibition mechanism of L-DOPA on L-tyrosine-induced $\left[\mathrm{Ca}^{2}\right]_{i}$ elevation is needed to examine in the future.

Shinozaki et al. (10) reported that $\mathrm{BH}_{4}$ content in vessels is decreased in fructose-fed rats (a model of insulin resistance with endogenous hyperinsulinemia). 
The activities of GTP cyclohydrolase I (GTPCII), the enzyme of $\mathrm{BH}_{4}$ synthesis, and dihydropteridine reductase (DIIPR), the recycling enzyme of $\mathrm{BH}_{4}$, have been shown to be decreased in diabetes (17). In streptozotocin-induced diabetic brain, DHPR activity is also reduced (11). Under diabetes mellitus, $\mathrm{BH}_{4}$ content may be decreased by downregulating the key enzymes of $\mathrm{BH}_{4}$ synthesis. In diabetic $\beta$-cells, $\mathrm{BH}_{4}$ content also seems to be decreased. We previously reported that insulin stimulates $\mathrm{BH}_{4}$ synthesis in endothelial cells $(18,19)$. In this study, the decrease in $\mathrm{BH}_{4}$ content stimulated L-tyrosine-induced $\left[\mathrm{Ca}^{2}\right]_{\text {i }}$ elevation. We previously also suggested that a decrease in $\mathrm{BH}_{4}$ content promotes the L-arginine-induced $\left[\mathrm{Ca}^{2}\right]_{i}$ elevation (12). Therefore, we speculated that the decrease in $\mathrm{BH}_{4}$ content under diabetic conditions, may stimulate $\mathrm{BH}_{4}$ synthesis via the enhancement of insulin secretion as one of the cell defense system, since $\mathrm{BH}_{+}$has antioxidative activities $(20,21)$.

In conclusion, our findings suggest that endogenous $\mathrm{BH}_{4}$ may negatively regulate L-tyrosine-indueed insulin secretion in $\beta$-cells through the reduction of $\mathrm{L}$ tyrosine-induced $\left[\mathrm{Ca}^{2}\right]_{i}$ elevation. The physiological role of $\mathrm{BH}_{4}$ in $\mathrm{B}$-cells should be examined in the future.

\section{References}

1 Nelson, TY, Gaines, KL. Rajan. AS. Berg, M. Boyd, AE, 3rd. Increased cytosolic calcium. A signal for sulfonylurea-stimulated insulin release from beta cells. J Biol Chem 1987; 262: 2608-2612.

2 Komatsu, M, Yokokawa, N. Takeda, T. Nagasawa. Y, Aizawa, T, Yamada, T. Pharmacological characterization of the voltage-dependent calcium channel of pancreatic B-cell. Endocrinology 1989: 125: 2008-2014.

3 Regazzi, R, Li, GD, Deshusses, J, Wollheim. CB. Stimulus-response coupling in insulin-scereting HIT cells. Effects of secretagogues on cytosolic $\mathrm{Ca}^{2-}$, diacylglycerol, and protein kinase $\mathrm{C}$ activity. J Biol Chem 1990; 265: 15003-15009.

4 Itoh, Y, Kawamata, Y, Harada, M, Kobayashi, M. Fujii, R, Fukusumi, S, Ogi, K, Hosoya, M, Tanaka, Y, Ucjima, H, Tanaka, H, Maruyama, M, Satoh, R. Okubo, S, Kizawa, H, Komatsu, H, Matsumura, F. Noguchi, Y, Shinohara, T, Hinuma, S, Fujisawa, Y. Fujino, M. Free fatty acids regulate insulin secretion from pancreatic $\beta$-cells through GPR40. Nature 2003; 422: 173-176.

5 Togashi, K. Hara, Y, Tominaga, T, Higashi, T, Konishi, Y, Mori, Y, Tominaga, M. TRPM2 activation by cyclic ADP-ribose at body temperature is involved in insulin secretion. EMBO J 2006; 25:
1804-1815.

6 Takasawa, S, Akiyama, T, Nata, K, Kuroki, M, Tohgo, A, Noguchi, N, Kobayashi, S, Kato, I, Katada, T, Okamoto, H. Cyclic ADP-ribose and inositol 1,4,5-trisphosphate as alternate second messengers for intracellular $\mathrm{Ca}^{2}$ mobilization in normal and diabetic $\beta$-cells. J Biol Chem 1998; 273: 2497-2500.

7 Kato. I. Yamamoto, Y. Fujimura, M. Noguchi, N. Takasawa, S. Okamoto, H. CD38 disruption impairs glucose-induced increases in cyclic ADPribose, $\left[\mathrm{Ca}^{2}\right]_{i}$, and insulin secretion. J Biol Chem 1999; 274: 1869-1872.

8 Shimizu, S. Ishii, M, Momose, K. Yamamoto, T. Role of tetrahydrobiopterin in the function of nitric oxide synthase, and its cytoprotective effect. Int J Mol Med 1998; 2: 533-540.

9 Nagatsu, T. Tyrosine hydroxylase: human isoforms, structure and regulation in physiology and pathology. Essays Biochem 1995; 30: 15-35.

10 Shinozaki, K, Kashiwagi, A, Nishio, Y, Okamura, T. Yoshida, Y, Masada, M, Toda, N, Kikkawa, R. Abnormal biopterin metabolism is a major cause of impaired endothelium-dependent relaxation through nitric oxide/ $\mathrm{O}^{2-}$ imbalance in insulin-resistant rat aorta. Diabetes 1999; 48: 2437-2445.

11 Hamon, CG, Cutler, P, Blair, JA. Tetrahydrobiopterin metabolism in the streptozotocin induced diabetic state in rats. Clin Chim Acta 1989; 181: 249-253.

12 Watabc, T, Ishii, M, Mori, Y, Shimizu, S, Kiuchi, Y. Decrease in tetrahydrobiopterin content promotes L-arginine-induced clevation of cytosolic calcium concentration in insulin-secreting cells. Pteridines 2003: 14: 119-125.

13 Lindstrom, P, Sehlin, J. Mechanisms underlying the effects of 5-hydroxytryptamine and 5-hydroxytryptophan in pancreatic islet. A proposed role for Laromatic amino acid decarboxylase. Endocrinology 1983; 112: 1524-1529.

14 Shimizu. S, Shiota, K, Yamamoto, S, Miyasaka, Y, Ishii, M. Watabe, T. Nishida, M. Mori, Y, Yamamoto, T, Kiuchi, Y. Ilydrogen peroxide stimulates tetrahydrobiopterin synthesis through the induction of GTP-cyclohydrolase I and increases nitric oxide synthase activity in vascular endothelial cells. Free Radic Biol Med 2003; 34: 1343 1352.

15 Ericson, LE, Hakanson, R, Lundquist, I. Accumulation of dopamine in mouse pancreatic B cell following injection of L-DOPA. Localization to secretory granules and inhibition of insulin secretion. Diabctologia. 1977;13:117-124.

16 Ahren, B, Lundquist, I. Effects of L-dopa-induced 
dopamine accumulation on ${ }^{+5} \mathrm{Ca}^{2}$ efflux and insulin secretion in isolated rat islets. Pharmacology 1985; 30: 71-82.

17 Shinozaki, K, Hirayama, A, Nishio, Y, Yoshida, Y, Ohtani, T, Okamura, T, Masada, M, Kikkawa, R. Kodama, K, Kashiwagi, A. Coronary endothelial dysfunction in the insulin-resistant state is linked to abnormal pteridine metabolism and vascular oxidative stress. J Am Coll Cardiol 2001; 38: 1821-1828.

18 Ishii, M, Shimizu, S, Nagai, T, Kiuchi, Y. Yamamoto, T. Insulin stimulates tetrahydrobiopterin synthesis in mouse brain microvascular endothelial cells. Pteridines 1999; 10: 213-216.

19 Ishii, M, Shimizu, S. Nagai, T, Shiota, K, Kiuchi, Y, Yamamoto, T. Stimulation of tetrahydrobiopterin synthesis induced by insulin: possible involvement of phosphatidylinositol 3-kinase. Int J Biochem Cell Biol 2001; 33: 65-73.
20 Kojima, S, Ona, S, lizuka, I, Arai, T, Mori, H, Kubota, K. Antioxidative activity of 5,6,7,8tetrahydrobiopterin and its inhibitory effect on paraquat-induced cell toxicity in cultured rat hepatocytes. Free Radic Res 1995; 23: 419-430.

21 Ishii, M, Shimizu, S, Momose, K, Yamamoto, T. Reduction by tetrahydrobiopterin of $\mathrm{H}_{2} \mathrm{O}_{2}$-induced endothelial cell injury. Pharmacol Toxicol 1998; 82: $280-286$. 